\title{
Art Matters: reconfiguring the relationship between art and its materiality
}

\author{
Pau Alsina \\ Ana Rodríguez Granell \\ Lecturers, Arts and Humanities Department (Open University of Catalonia, UOC)
}

Published: June, 2015

Materials and technologies of contemporary art invite us to rethink both the role that they play in the articulation of artistic practices and infrastructure and the theoretical frameworks that reflect the role of materiality itself in the history of art. This implies new methodological challenges and important epistemological transformations in the study of art; challenges that must be analysed, discussed and contrasted with their long and fertile tradition. Key issues, such as the distribution of agencies involved in research and artistic practice, temporal causality lines, interconnection between materiality and discursivities, the role of technology and society, the space and location of art become particularly relevant from the challenges raised today.

The theme of the node is not exactly new to Artnodes, which in recent years has published various articles that have dealt with the concept as well as monographs discussing the relationship between art and materiality.

For instance, our issue No. 12, coordinated by Jamie Allen and titled "The Materiality of the Media: New Materialisms through Media, Art and Technology" or issue No 14 coordinated by Beatriz Revelles-Benavente, Ana M. González Ramos and Krizia Nardini titled "New Feminist Materialism: engendering an ethic-ontoepistemological methodology".

This monograph brings together a number of articles that reconfigure the relationship between art and materiality: contributions focusing on theoretical, methodological and epistemological approaches as well as rather empirical studies on or from art practices and infrastructures. The selection of articles is linked, on the one hand, to the open call we made from the magazine and, on the other hand, to the Art Matters International Congress, co-organised by Barcelona University, Hangar and the Unversitat Oberta de Catalunya that was held in December 2014 at the UB School of History of Art. All of this linked to research projects on Art, Architecture and New Materialities with the references HAR201459261-C2-1-P and HAR2011-30347-C02-01.

In the first article of the node, Helen Pritchard and Jane Prophet use the concept of diffraction proposed by Karen Barad to reassess the relationship between contemporary art and new media art, rethinking the controversy between them, which incidentally was the focus of our issue No 11, which was coordinated by Edward Shanken. Then, Nuria Peist proceeds from the consideration of the non-hierarchical relationship between physical subject and material object raised by philosopher Maurice Merleau-Ponty, to analyse the phenomenological and interrelational links between technology, people and contemporary art. In this sense, this connects with the paper presented by Carles Sora and Sergi Jordà that starts from a phenomenological and cognitive approach to the role of the body in the construction of perception to present and discuss a selection of interactive works and associated time frames, forcing us to rethink our relationship with contemporary images.

Sergio Martínez Luna starts from concepts such as that of epistemic objects, offered by Karin Knorr Cetina, or Jacques Rancière's aesthetic regime to think about new production methods and sharing of knowledge in interdisciplinary or transdisciplinary initiatives. Thus, from an interdisciplinary discipline par excellence 


\section{artnodes}

http://artnodes.uoc.edu

such as nanotechnology, Tincuta Heinzel invites us to reflect on the paradoxical nature of nano-objects while at the same time she analyses the relationship between an imperceptible material and its ostensible manifestation forms, speculating through a reconstruction of some of Joseph Beuys's works as a strategy of approach to the aesthetics of imperceptibility.

On a different scale, María de la 0 Artiles Burgos and Javier Boned Purkiss' paper focuses on modern architecture and the phenomenon of transparencies focusing on two key concepts such as materiality and virtuality. And on a different continent, Ana del Castillo and Jesús Fernando Monreal discuss the importance of a set of artistic practices in Mexico linked both to the high-tech infrastructure of the Centro Nacional de Artes and to the cultural environment of technological obsolescence in the period studied.

In another approach to the theme of art and materiality, Lorena Lozano starts from the review of some perspectives on the processes
Art Matters: reconfiguring the relationship between art and its materiality

of natural and organic life in relation to the artistic and scientific practices, based on a couple of her case studies and fieldwork. And in a related direction, Christian Alonso's article explores the role of artistic practice to question, answer and understand our position in the world under the terms of the Anthropocene, and this critical analysis done by studying several art projects featured in a group exhibition. Finally, to close the monograph node, Claudia Kozak discusses digital literature from the study and analysis of its own materiality, in this case inspired by considerations about the so-called dematerialization of informational works developed in Argentina in the nineteen sixties.

A total of ten articles that deal with art and materiality from different complementary perspectives - texts that echo each other providing interesting areas of convergence and divergence that invite us to think from multiple locations from where they are presented. We hope you enjoy them.

\section{Recommended quotation}

ALSINA, Pau; RODRÍGUEZ GRANELL, Ana (coord.) (2015) "Art Matters" [online node]. Artnodes, no. 15, pp. 2-4. UOC. [Accessed: dd/mm/yy] $<$ http://journals.uoc.edu/ojs/index.php/artnodes/article/view/n15-alsina-rodriguez/n15-alsinarodriguez-en>

$<$ http://dx.doi.org/10.7238/a.v0i15.2672>

Els textos publicats en aquesta revista estan subjectes -llevat que s'indiqui el contrari- a una llicència de Reconeixement-Sense obres derivades 3.0 Espanya de Creative Commons. Podeu copiar-los, distribuir-los i transmetre'ls públicament sempre que citeu l'autor, la revista i la institució que els publica (IDP. Revista d'Internet, Dret i Política; UOC); no en feu obres derivades. La llicència completa es pot consultar a http://creativecommons.org/licenses/by-nd/3.0/es/deed.ca. 


\section{artnodes}

http://artnodes.uoc.edu

Art Matters: reconfiguring the relationship between art and its materiality

\section{CV}

\section{Pau Alsina}

palsinag@uoc.edu

@paualsina

Lecturer in Art Studies and Humanities (UOC)

Editor of Artnodes

PhD in Philosophy from the Universidad de Barcelona. Lecturer at the School of Arts and Humanities at the Universitat Oberta de Catalunya, where he coordinates and teaches contemporary art and thought. Lecturer of the master's programme on Commissariat of Digital Arts at the Escuela Superior de Diseño, affiliated with the URL. Editor of Artnodes, a journal focusing of the intersections between art, science and technology. He is co-founder and member of the editorial team of YASMIN, a Mediterranean art, science and technology (ACT) network (<http://www2.media.uoa.gr/yasmin/>) fostered by Unesco Digiarts, Leonardo/ISAST, Olats, Artnodes/UOC and the University of Athens. He has collaborated with various public and private institutions in shaping cultural policies related to art and digital culture. It has also promoted interdisciplinary events such as the Sinergia meeting or the International Conference on Art and Materiality. He has published several books, book chapters and articles on the intersections between art, science and technology, and contemporary thought. He is currently investigating the development of a neo-materialistic approach to art and contemporary culture.

UOC

Av. Tibidabo, 39-43

08035 Barcelona

\section{CV}

\section{Ana Rodríguez Granell}

arodriguezgrane@uoc.edu

Lecturer in Art Studies and Humanities (UOC)

Executive editor or Artnodes

$\mathrm{PhD}$ in Art History from the University of Barcelona. She is currently a lecturer at the School of Arts and Humanities at the UOC, where she coordinates and teaches in the degree and master courses of Humanities, linked to the history of cinema, media and art history. Since 2008 she participates in several research groups and funded projects related to artistic practices, digital culture and cinema. Her latest research and publications focus on the concept of modernity, its links with the emergence of critical discourse from artistic practices or on the ability of political agency of certain groups linked to the audiovisual production.

UOC

Av. Tibidabo, 39-43

08035 Barcelona

\section{$\square$ UOC \\ Universitat Oberta de Catalunya}

